\title{
The features of economic behavior of the urban population in the ethnic the region of Kashubia (Kashuby / Cassubia)
}

\begin{abstract}
The article refers to the economic analysis of behavior of the urban population living in the ethno-region of Kashubia. The study measured the intensity of local entrepreneurship in the cities, the effectiveness of obtaining EU funds, as well as the assessment of the local units' own income. The study was conducted in three spatial dimensions, treating the Tri-City, the cities of Kashubia and the remaining cities of Pomerania as separate entities. The analysis showed a clear separation of the TriCity as a metropolitan area and the main center of economic growth, accumulating the largest share of economic, social and innovation capital. In almost every respect, the Kashubian cities confirmed a strong concern for the development of local entrepreneurship, which makes them more dynamic in comparison to other cities of Pomerania.
\end{abstract}

Keywords

Entrepreneurship • ethnic region $\bullet$ city $\bullet$ Kashubia $\bullet$ Poland

(c) University of Warsaw - Faculty of Geography and Regional Studies

\author{
Paweł Czapliński \\ Wioletta Szymańska² \\ ${ }^{1}$ Institute of Geography and Regional Studies \\ Pomeranian University in Słupsk \\ e-mail:somma@o2.pl \\ 2Institute of Geography and Regional Studies \\ Pomeranian University in Słupsk \\ e-mail: szymanskaw@apsl.edu.pl \\ Received: 28 September 2012 \\ Accepted: 7 March 2013
}

Introduction

Today, when technical and technological progress is proceeding at an ever increasing pace, closely connected with globalization and civilization based not only on knowledge and innovation, but also on the information society, entrepreneurship becomes an integral part of innovation. As noted by Greblikaite \& Krisciunas (2012), innovation at the local level is related mainly to places in which companies and institutions look for the most favorable conditions for their location and functioning. When it comes to the place of the local segment in the innovation system, it is provided by the union of municipalities, enterprises, companies and institutions creating projects characterized by high technological and ecological standards.

Innovation in local economies should be understood not only as local scientific activities, but also as the innovation and ingenuity of private sector enterprises which affects the development of the endogenous segment of the local economy. R. Domański (2000), J. de la Mothe \& G. Mallory (2006) and Ch.V. Hawkins (2011) discussed the phenomenon of selfstrengthening development of the economy in cities, which takes place when there is consistent feedback between elements of the economy, including investment in human capital, creativity and innovation, social capital, institutions organizing co-operation of different entities, comparative advantages and competitiveness. Local entrepreneurship for the development of the city on the part of the authorities, community leaders, policy makers, as well as people themselves becomes a value in itself, since it is conducive for creating a climate appropriate for developing broadly understood cooperation and thus competitiveness and innovation.
The phenomenon of entrepreneurship should be understood as an attitude involving motivation and skills to identify market opportunities in order to produce a new value or economic success. If we assume that modern economic existence forces permanent competition, the use of creativity or innovation by an enterprise is a prerequisite for participation in the market and may even ensure the possibility of changing it. Therefore entrepreneurship within the urban population, especially in smaller towns, is not only positive or recommended but also necessary.

Ethnic regions are special economic areas, since their economic development combines with the cultivation of traditions, which often determines the direction of the modern forms of activity. This is mentioned by many researchers dealing with ethnic regions e.g. W. Phansuwan, S. Photisan and A. Kangrang (2010) who focused on commercial production of traditional products of silk in Lower-Isan in Thailand, S. Chaiyatorn, P. Kaoses and P. Thitphat (2010) who discussed the strengthening of tourism development and the cultivation of ethnic identity in Thailand, as well as L. Zhang and F. Wang (2010) who referred to the socio-economic development through the strengthening of education and improvement of the quality of human capital in ethnic regions of China. The study of entrepreneurial behavior in the ethnic regions of Europe has a neo-liberal and post-modern context (Bertuglia, Lombardo \& Nijkamp 1997). Many authors have discussed the operation of small and medium-sized enterprises in the regions without tying them to specific behaviors, but rather with a market economy, legal and administrative determinants and the socio-economic structure of the region (for example: Lybaert 1998, Bishop 2008, Sleutjes, Oort \& Schutjens 2012). Among the few comparative studies, 
N. Bosma and V. Schutjens (2011) pointed out the significant differences in the behavior and attitudes of entrepreneurship in 127 regions of Europe, naming the regional potential as an important factor in these differences. Whereas, Davidsson P. and J. Wiklund (2001), or Q. Wang (2012) shows the influence of cultural factors on the behavior of entrepreneurs and postulate for the inclusion of the studies on ethnic communities entrepreneurship to the interdisciplinary multiscale spatial studies.

According to the previous studies carried out by M. Dutkowski (2002) in the Kashubia region, the level of measurable entrepreneurship was higher in cities than in rural areas. This phenomenon applies to different types of entrepreneurship starting from the most basic, known simply as "resourcefulness", to complex intellectual entrepreneurship (Kwiatkowski 2002). Therefore, further discussion is related to the urban population of the ethnic region of Kashubia in relation to other cities of Pomerania.

The main objective of this paper is to determine whether the behavior and therefore the effects of entrepreneurship of Kashubian urban population differ from the economic behavior of people in other cities of Pomerania. The detailed explanations show the level and direction of these differences (active - passive communities).

The research problem is therefore a question of the uniqueness of urban population entrepreneurship in the ethnic region of Kashubia.

\section{Research Methodology}

The measurement of the economic effects of entrepreneurship in the Kashubian cities have been carried out according to the assessment of intensity of 11 indicators in 3 categories of economic data obtained from the Central Statistical Office. The selection was performed on the basis of the logical interpretation of importance of these measures for competitiveness and economic development of cities and they included:

\section{Indicators of entrepreneurship}

- Total number of entities per 10,000 inhabitants

- The number of newly registered enterprises per 10,000 inhabitants

- Number of de-registered entities per 10,000 inhabitants

- Balance of registered and de-registered businesses in 2009

2. Funds from the EU

- Funds obtained from the EU in 2006-2009 in PLN per inhabitant

- EU funds for investment received in 2006-2009 in PLN and per inhabitant

3. Income of local government units - cities of the Pomeranian province

- Total income per inhabitant in PLN - average for 2002-2009

- Own income per inhabitant in PLN - average for 2002-2009

- Share of income tax receipts from individuals for 2002-2009 per inhabitant in PLN

The analysis has been performed for three groups - the Kashubian cities, the Tri-City and other cities of the region. This delimitation results from the intra-regional differentiation of the Pomeranian province in terms of the nature and intensity of running a business activity. The Tri-City agglomeration is of particular interest, especially the Tri-City (Gdynia, Sopot, Gdańsk), where the highest concentration of capital, knowledge and information can be observed. The "big city" character, increasingly liberal customs and morals, as well as citizens' behaviors that are typical of global cities and most certainly of information and knowledge-based societies, make this location more similar to other metropolitan areas than other cities in the region.

The Słupsk sub-region with the city of Słupsk exhibits a kind of separateness. It is an area characterized by a historical distinctness from the Kashubia region, since it remained under German control for a longer time. Nevertheless, the area is connected with Kashubia to some extent thanks to Slavic culture. In more modern history, the biggest population exchange in comparison to other areas in the Pomerania province, the result of restoration of its lands after the World War II, is an expression of this individuality. This led to the disappearance of tradition as well as the links between people, which consequently caused a decrease in their attachment to the region.

The study revealed that inhabitants of Kociewie (an ethnocultural region in the eastern part of the Tuchola Forest), Powiśle (a contemporary geographic region covering areas of the east bank of the lower Vistula) and Żuławy (the alluvial delta area of the Vistula) were residents of the Pomerania region displaying the closest attachment to Poland. The cities located directly on the coast and in the Puck Bay constitute an exceptional group. Since this is an attractive location for the development of tourism and the maritime economy, increased activity by inhabitants and opening of businesses by other people of the Tri-City, Słupsk or medium-sized Pomeranian cities, provide the region with better economic results for the local economy.

The Kashubian region is the most culturally defined area. Historical conditions, the stability of social behaviors as well as the inhabitants' strong ethnic identity clearly mark its separateness. As a result, the empirical considerations are limited to three groups of cities: firstly, the Kashubian cities without the Tri-City, secondly - the Tri-City (Gdańsk, Gdynia, Sopot) itself and thirdly, other cities of the region. This was to present the differences between local economic attitudes of the Kashubian cities and other cities of the region, as well as the Tri-City, which received special treatment as it is a metropolitan area.

The cultural region of Kashubia

According to the ethnic criteria of J. Mordawski (2008), the cultural region of Kashubia located in the province of Pomerania, covers an area of about $7,000 \mathrm{~km}^{2}$, which represents nearly $35 \%$ of the territory of the entire region. These areas are not equally inhabited by the Kashubian people and the communities do not cultivate Kashubian traditions and customs to the same extent. Among the 16 cities of Kashubia, the most "Kashubian" seem to be Kartuzy, Kościerzyna, Puck, Żukowo, Brusy and Jastarnia, since the total number of the Kashubian ethnic population in these cities exceeds $80 \%$ (Tab. 1). At the same time, social and cultural activities prove that the communities of Wejherowo, Puck, Kartuzy, Żukowo, Kościerzyna and Bytów promote the Kashubian language and culture in the most active way. Many "native" Kashubian people live in the Tri-City (about 15\%), although their share in total population does not exceed $15 \%$ in Gdynia, $5 \%$ in Gdańsk and 6\% in Sopot (Mordawski 2008, pp. 64-69).

The number of Kashubian people living in individual cities does not correspond to their importance in the cultural hierarchy. For example, there are many controversies as to which city should be considered the Kashubian capital. According to the "Geographical Dictionary of the Polish Kingdom" published in 1880, the capital of the "land of Kashubia" was Wejherowo (Geographical Dictionary of the Polish Kingdom, 1893, pp. 193), which is also referred to as the largest city and "spiritual" capital of Kashubia. Manifestations of Wejherowo's care for the preservation of the Kashubian culture include: the Calvary of Wejherowo, the Literature and Music Museum of the Kashubian-Pomeranian Region, as well as Kashubian-Pomeranian University of which the whole Kashubian community is very proud (Obracht-Prondzyński 2007, p. 37). One of 
MISCELLANEA GEOGRAPHICA - REGIONAL STUDIES ON DEVELOPMENT

Vol. 17 • No. 2 • 2013 • pp. 30-37 • ISSN: 2084-6118 • DOI: 10.2478/v10288-012-0032-3

Table 1. The Kashubian population in the cities of the Kashubia cultural region (2005)

\begin{tabular}{|c|c|c|c|c|c|}
\hline City & Population & $\begin{array}{c}\text { Estimated number of } \\
\text { Kashubians }\end{array}$ & $\begin{array}{l}\text { Estimated number of } \\
\text { half- Kashubians }^{1}\end{array}$ & $\begin{array}{c}\text { Percentage } \\
\text { share of } \\
\text { Kashubians }\end{array}$ & $\begin{array}{c}\text { Percentage } \\
\text { share of half- } \\
\text { Kashubians }\end{array}$ \\
\hline Brusy & 4,546 & 3,500 & 218 & 77.0 & 4.8 \\
\hline Bytów & 16,788 & 7,672 & 3,492 & 45.7 & 20.8 \\
\hline Chojnice & 8,000 & 2,184 & 648 & 27.3 & 8.1 \\
\hline Gdańsk & 450,000 & 21,150 & 25,200 & 4.7 & 5.6 \\
\hline Gdynia & 252,791 & 37,691 & 36,200 & 14.9 & 14.3 \\
\hline $\mathrm{Hel}$ & 3,956 & 514 & 870 & 13.0 & 22.0 \\
\hline Jastarnia & 4,032 & 2,423 & 835 & 60.1 & 20.7 \\
\hline Kartuzy & 15,303 & 12,579 & 1,362 & 82.2 & 8.9 \\
\hline Kościerzyna & 23,031 & 18,931 & 1,727 & 82.2 & 7.5 \\
\hline Puck & 11,319 & 8,070 & 1,675 & 71.3 & 14.8 \\
\hline Reda & 18,360 & 7,436 & 2,497 & 40.5 & 13.6 \\
\hline Rumia & 44,454 & 17,915 & 7,735 & 40.3 & 17.4 \\
\hline Sopot & 40,075 & 2,324 & 3,166 & 5.8 & 7.9 \\
\hline Wejherowo & 44,977 & 18,396 & 10,075 & 40.9 & 22.4 \\
\hline Władysławowo & 14,791 & 7,780 & 3,446 & 52.6 & 23.3 \\
\hline Żukowo & 6,294 & 2,958 & 2,379 & 47.0 & 37.8 \\
\hline
\end{tabular}

${ }^{1} A$ half-Kashubian person has one parent who is Kashubian

Source: (Mordawski 2008, pp. 69-70)

the leading researchers of the Kashubia region, Jan Mordawski and the Kashubian-Pomeranian Association, which is the main association of the Kashubians, consider Gdańsk as the capital of Kashubia - a city that "has always been the capital fortress of the Kashubians and the Pomeranians on the Vistula River" (Borzyszkowski, Mordawski, Treder 1999, p. 10). However, due to its landscape and tourist attractions, Kartuzy is also taken into account as the center of Kashubian Switzerland.

Features of the Kashubian community

In the identification of a "living" cultural region, the most important role is played by its community, as well as the strength of its cultural identity. Although the Kashubian community had already existed for several hundred years, it only began to reconstruct its heritage in democratic Poland, that is at the end of the $20^{\text {th }}$ century. In the history of the Kashubian region, many phenomena are rooted in the distant past but still have implications for the present population of the region. These include the legacy of long-standing relationships with Germany, the effects of living in a border area, the durability of strong family ties, a devotion to religion, a specific mentality and social attitudes. Moreover, the length of residence on the Kashubian territory - "our small homeland" - is also very important (ObrachtProndzyński 2007, p. 5). This fact is well illustrated by J.K. Wilson (2008), who analyzed the process of Germanization of the Kashubians during the Partition using the example of forest management. The Germans referred to the Kashubian people as backward, lazy and not able to understand the concept of someone else's property. Their behavior was perceived as an economic, not a political problem, although they made the implementation of the
German management policy difficult. The Kashubians marked their independence and attachment to Poland by ignoring the stringent constraints concerning the usage of forest goods for example, which were treated by Germans as state property, while the Kashubians considered them public property. Nevertheless, the long-term functioning according to the rules of the German economy has left its mark on Kashubians' behavior.

In post-War Poland, the climate for stressing cultural differences was not favorable because of ideological reasons. It was not until after the political changes in Poland at the end of the 20th century and accession to the European Union that marking traditional cultural identity in various Polish regions became possible. The tendency to emphasize separateness coincided with socio-economic changes resulting from societal development and globalization. In Kashubia, rural areas have been visibly affected by the transformation; old jobs disappeared (e.g. wheelwright) or changed their profile (e.g. blacksmithing has become artistic blacksmithing), the range of marine coastal fishing declined and residential architecture changed (ObrachtProndzyński 2007, p. 6). These changes arising from modernization overlap with the effects of accession to the EU, as a result of which Kashubia is becoming a tourist heartland, fishermen are turning into tourist businessmen while rural areas are being transferred into agro-tourist destinations. The service sector begins to dominate although it is still strong in the Kashubian crafts, such as carpentry or furniture manufacturing, which are traditionally associated with the region. These changes affect the cultural sphere and Kashubian identity as well as the sense of identification with the region. Many researchers argue that the identity of this social group, based on Kashubian culture and 
Table 2. Entrepreneurship in the cities of Pomerania (2009)

\begin{tabular}{|c|c|c|c|c|}
\hline Specification & $\begin{array}{c}\text { Entrepreneurship rate } \\
\text { (number of entities per } \\
\mathbf{1 0 , 0 0 0} \text { inhabitants) }\end{array}$ & $\begin{array}{c}\text { Newly registered } \\
\text { entities } \\
\text { (per 10,000 inhabitants) }\end{array}$ & $\begin{array}{c}\text { Deregistered entities } \\
\text { (per 10,000 inhabitants) }\end{array}$ & Net balance in 2009 \\
\hline Kashubian cities & $1,361.5$ & 222.9 & 102.8 & 120.1 \\
\hline Tri-City & $1,613.0$ & 142.7 & 77.7 & 65.0 \\
\hline the remaining cities & $1,289.7$ & 110.1 & 102.3 & 7.8 \\
\hline
\end{tabular}

Sources: Business entities, Local Data Bank, the Central Statistical Office, Warsaw, www.stat.gov.pl dated. 22/01/2012, own elaboration

language, has been losing its importance in favor of elements such as Kashubian origin, family ties, being born in Kashubia, the fate of the community, native land, common customs, intellectual and artistic heritage and common institutions etc. This process, which is in line with global trends, leads to a shift from a passive and inconsiderate approach of clinging on to native culture and values, to a more active search for individual and group identity which is called the "new ethnicity" (Obracht-Prondzyński 2007, pp. 13-15).

With regard to economic attitudes, M. Dutkowski (2002) argues that the Kashubians display specific characteristics of entrepreneurial stances. He considers the following to be the most important:

1. Within the sphere of motivation - self-confidence and Divine Providence, the desire to ensure a dignified family life, perseverance in pursuing goals.

2. Within the sphere of rules relating to conducting a business - reliability, legality, prudence, thrift, stability, traditionalism.

3. Within the sphere of the preferred form of enterprise private, small, or medium, family-run, urban, local.

4. Within the sphere of enterprise characteristics - flexibility and responsiveness, passivity towards competition, openness to new ideas.

Effects of the economic activity of the urban population in Kashubia

As a result of such distinctiveness of attitudes of the Kashubian population there are significant differences in the effects of the economic activities of the urban population of the region. The overall rate of company formation (Tab. 2) clearly shows the attractiveness of the Tri-City business and its stability over time, which is reflected by the relatively small proportion of deregistered entities in the National Official Register of Business Entities. In this respect, the cities of Kashubia develop to a greater extent when compared the rest of the region since they have a higher intensity of entrepreneurship, as well as double the levels of new company formation. At the same time, the rate of de-registration of business entities remains the same level in comparison to other cities of Pomerania and slightly higher than in the Tri-City. This allows us to conclude that the inhabitants of Kashubian cities start their business with greater efficiency which results in a high positive balance of entrepreneurship. It is therefore confirmed that the characteristics of resourcefulness and flexibility, responsiveness, as well as openness to new ideas in running businesses, provide the basis for competitive local economies in Kashubian cities.

Spatial analysis of the economic behavior of the population of each city (Fig. 1) indicates that the highest level of entrepreneurship is observed in the coastal cities, that is among the Kashubian cities of Jastarnia, Władyslawowo, Sopot, Hel and Pruszcz Gdański. Furthermore, attention should be paid to the nonKashubian cities such as Łeba and Krynica Morska since their high rates of entrepreneurship result from their small populations and rapidly developing tourist activities. The indicator studied places the Tri-City very highly, as well as towns located in the agglomeration area (Wejherowo, Rumia, Reda, Pruszcz Gdansk). This results from their convenient location on the seafront as well as the metropolitan effects, which lead to a greater concentration of economic activity. Among the cities of Kashubia, the lowest levels of entrepreneurship are observed in Chojnice, the most southern and western point of the region, and in Kościerzyna which is located in the Kashubian Lake District and has a high proportion of forest and agricultural land. Despite higher values for Kashubian cities than for other cities in the region (excluding the Tri-City), the entrepreneurship rate seems to show greater dependence on geographical location (coastal cities and towns associated with the agglomeration) than on the ethnicity. To determine the significance of this dependency requires however further research.

Nowadays an important measure of care for the locality is the ability and effectiveness in acquiring EU funds in order to improve economic and social competitiveness. Studies by P. Swianiewicz (2012) show that local authorities and their subordinate units are very important beneficiaries of EU funds. The largest of them are local units (municipalities), particularly large cities, which receive $40 \%$ of all funds obtained by local governments. The size of the funds used by the municipality results mainly from the allocation of financial resources under the Operational Programme Infrastructure and Environment (OPI\&E). As far as other programs are concerned, this relationship is not as clear. The situation is similar in the province of Pomerania, since the largest pool of obtained and used EU funds belongs to the local authorities of large cities - in this case the Tri-City (Tab. 3), which leads both in terms of the total funds obtained as well as funds obtained per inhabitant in 2006-2009. This is not surprising because factors concerning the settlement center hierarchy and benefits of the agglomeration are taken into account.

When compared to other cities of the region, the Kashubian cities obtained slightly less EU and investment funds in total and these constituted about $70 \%$ of the funds obtained by other cities of the region and about $19 \%$ of the funds received by the Tri-City. However the Kashubian cities display greater flexibility and efficiency in terms of funds obtained per inhabitant. The Kashubian cities obtained $30 \%$ more in terms of total funds and about $35 \%$ more in terms of investment funds per inhabitant in comparison to the remaining cities of the region.

The detailed indication of the cities obtaining the most EU funds per inhabitant gives a clear picture of the effectiveness of the Kashubian cities (Fig. 2). Cities that have the above-average levels of obtained funds per inhabitant and thus deserve an honorable mention are Jastarnia (7,339 PLN/inhabitant), Kościerzyna (1429), Władysławowo (511), Brusy (489) and Chojnice (420). Of all the non-Kashubian cities (with the exception of the Tri-City), 


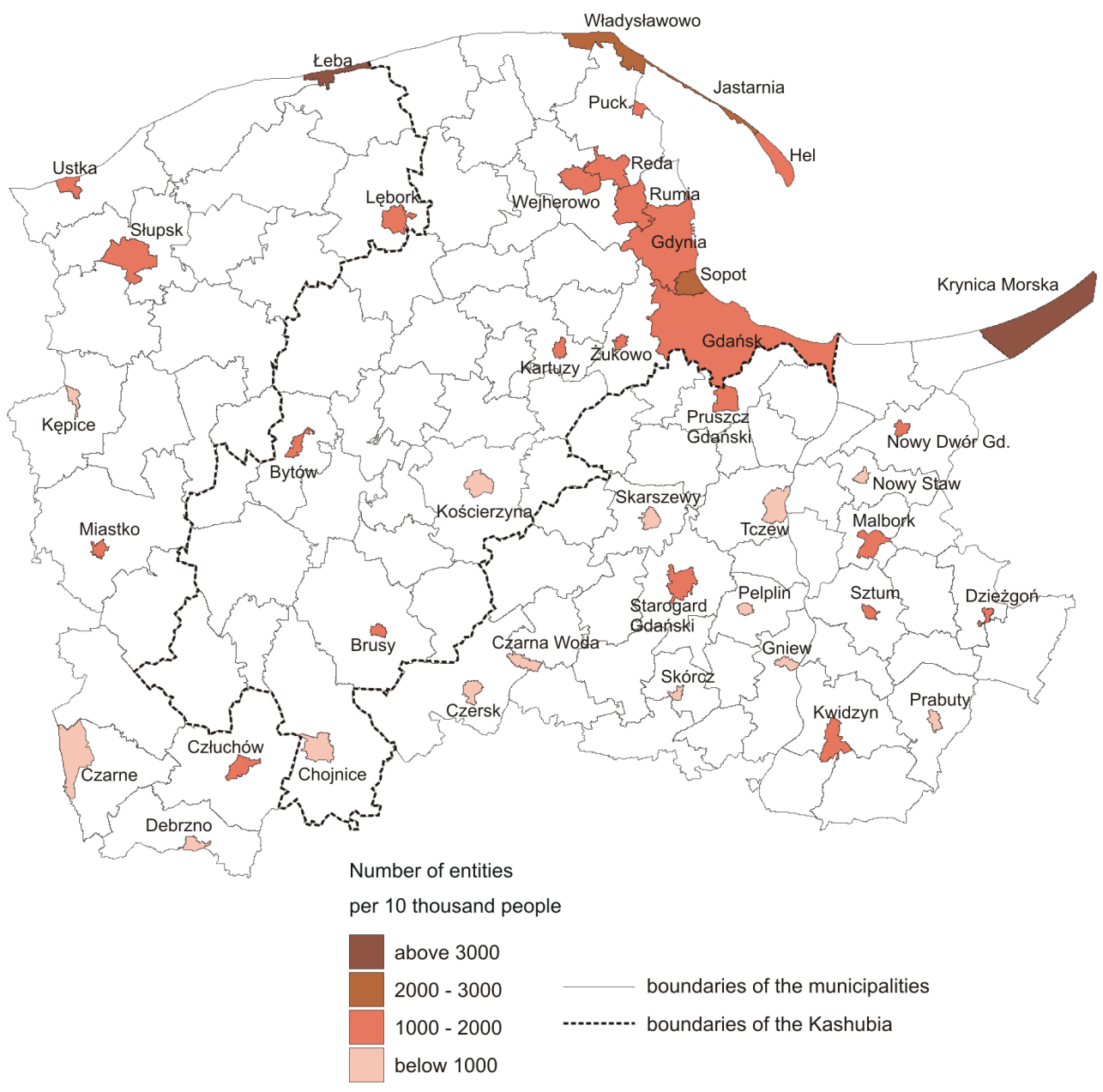

Fig. 1. Entrepreneurship rates in cities of the Pomerania province and the Kashubian region in 2009

Source: Business entities, Local Data Bank, the Central Statistical Office, Warsaw, www.stat.gov.pl dated. 22/01/2012, own elaboration

Table 3. Funds obtained from the EU in the cities of Pomerania in 2006-2009

\begin{tabular}{|c|c|c|c|c|}
\hline \multirow{2}{*}{ Specification } & \multicolumn{2}{|c|}{ EU funds } & $\begin{array}{c}\text { Of which investment } \\
\text { funds }\end{array}$ & \\
\cline { 2 - 5 } & $\begin{array}{c}\text { Total } \\
\text { (PLN) }\end{array}$ & $\begin{array}{c}\text { per inhabitant } \\
\text { (PLN) }\end{array}$ & $\begin{array}{c}\text { Total } \\
\text { (PLN) }\end{array}$ & $\begin{array}{c}\text { Per inhabitant } \\
\text { (PLN) }\end{array}$ \\
\hline Kashubian cities & $96,285,451$ & 317.8 & $85,862,372$ & 283.4 \\
\hline Tri-City & $490,580,435$ & 660.3 & $471,678,206$ & 634.9 \\
\hline Remaining cities & $137,955,030$ & 243.8 & $119,089,832$ & 209.6 \\
\hline
\end{tabular}

Source: Revenue and expenditure of local government units, Local Data Bank, the Central Statistical Office, Warsaw, www.stat.gov.pl dated. 22/01/2012, own elaboration

the cities situated on the coast perform best, i.e. Łeba (3117 PLN/ per inhabitant), Ustka (592) and Krynica Morska (484).

Analysis of the Ministry of Regional Development's database of EU projects ${ }^{1}$ reveals that by June 2012, Jastarnia used over PLN 33.5 million as a stand-alone beneficiary or a co-beneficiary of EU funding, Kościerzyna used nearly PLN 49 million for 13 projects, Władyslawowo - over PLN 11.4 million (10 projects), Brusy - 26.7 million PLN (9) and Chojnice - PLN 44.4 million (11). In comparison, the city of Gdańsk participated in 38 ${ }^{1}$ European funds www.mrr.gov.pl dated. 15/08/2012 projects and acquired more than PLN 698 million, Gdynia had 28 projects (PLN 618 million) and the city of Sopot had 18 projects (PLN 190 million).

This clear difference in both the quantity and size of funds is largely due to the implementation of expensive projects in large units, such as the Infrastructure and Environment Operational Programme, as well as the Innovative Economy Operational Programme. Smaller entities often do not have their own contribution to such investments, but their needs are also far smaller. 


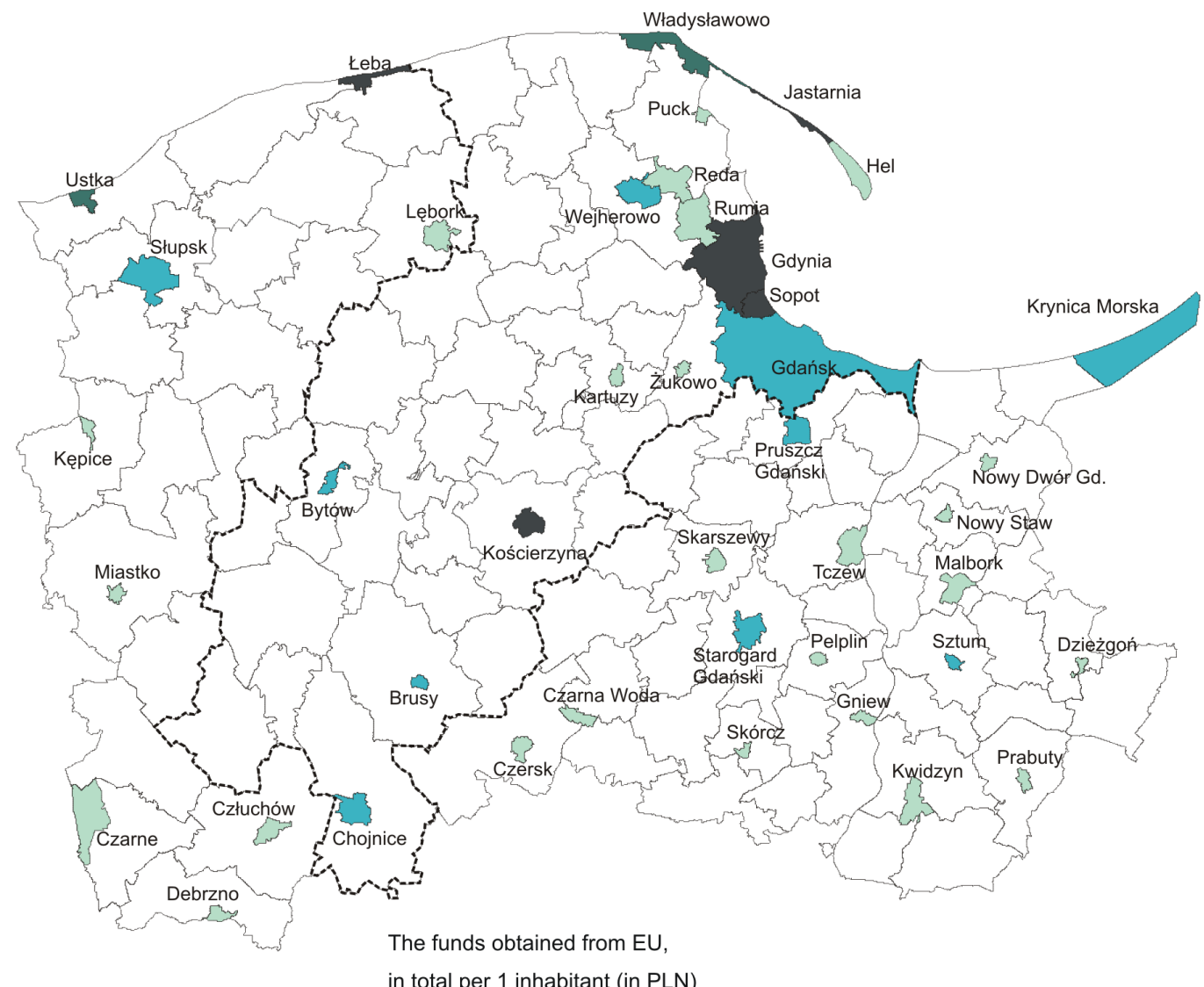

in total per 1 inhabitant (in PLN)

above 1000

$500-1000$ boundaries of the municipalities

$200-500$

below 200

Fig. 2. EU funds obtained per inhabitant in the cities of Pomerania in 2006-2009

Source: Revenue and expenditure of local government units, Local Data Bank, the Central Statistical Office, Warsaw, www.stat.gov.pl dated. 22/01/2012, own elaboration

Table 4. Average total income and own income of local governments

\begin{tabular}{|c|c|c|c|}
\hline Specification & $\begin{array}{c}\text { Total income } \\
\text { per inhabitant } \\
\text { (in PLN) }\end{array}$ & $\begin{array}{c}\text { Own income } \\
\text { per inhabitant } \\
\text { (in PLN) }\end{array}$ & $\begin{array}{c}\text { Participation in taxes from } \\
\text { individuals } \\
\text { per inhabitant } \\
\text { (in PLN) (2007-2009) }\end{array}$ \\
\hline Kashubian cities & 2,219 & 1,232 & 477 \\
\hline Tri-City & 3,577 & 2,434 & 1,368 \\
\hline Remaining cities & 2,310 & 1.143 & 404 \\
\hline
\end{tabular}

Source: Revenue and expenditure of local government units, Local Data Bank, the Central Statistical Office, Warsaw, www.stat.gov.pl dated. 22/01/2012, own elaboration

A good indicator of vitality of the local units are the revenues they generate (Tab. 4). In the case of smaller municipalities, it is an expression of a supportive climate for business, both by indigenous entities and by obtaining capital from outside.

The statement presented indicates to a large extent the dominance of the Tri-City, a major center of growth in the Pomerania province. In general, the Kashubian cities have a slightly lower average income per inhabitant in comparison to other cities of the region. Nonetheless, its income and share of natural persons in taxes per resident are significantly higher. This confirms the local predisposition of the Kashubian ethno-region, especially its urban communities, to careful but courageous implementation of economic solutions bringing tangible results in economic growth. 


\section{Conclusion}

Nowadays, ethnic regions (not only in Europe) are special economic areas trying to find their own way by skillfully joining economic development with the cultivation of traditions, while providing the basis for the improvement of their inhabitants' living conditions at the same time. By being identified with ethnic identity, the Kashubian region presents some specific features in comparison to the surrounding communities.

With regard to the question asked at the beginning of this paper: is the economic behavior of Kashubian cities differenet from other cities in the region? It should be emphasized that there is a distinctiveness of economic behavior in Kashubian cities and it is noted in the specific "Kashubian" entrepreneurship. The calculated hard indicators define a higher level of entrepreneurship, a higher level of obtaining EU funds (per inhabitant) and a higher level of own revenues for local governments in the Kashubian cities than in other cities of the province. In the other direction, the distance between the Kashubian cities and the Tri-City is being marked. The Kashubian cities do not have such a strong resilience in economic activities as the Tri-City which, as a metropolitan area, concentrates the greatest economic potential which means that ethnicity is not the most important development factor development. It follows that in the smaller towns there is no contradiction between cultivating traditions or creation of regional identity and the implementation of innovative entrepreneurial solutions. One could even say that this is a factor conducive to an active business.

It should be noted however, that the specific social behaviors of the residents of the Kashubian ethno-region overlap with other factors related to the overall level of national economic development, geographical situation and conditions of the geographical environment, that are predisposed to the development of tourism, agro-tourism, health resort business, industrial and special service areas etc. To some extent they may influence more strongly a faster pace of implementation of innovative solutions or flexibility in business. Selection is a very difficult task, because it is the weaving together of a number of factors that leads the formation of the genius loci of a place, even for economic aspects.

\section{References}

Bertuglia, CS, Lombardo, S \& Nijkamp, P 1997, 'An interpretative survey of innovative behaviour', in Innovative behaviour in space and time, ed. C.S. Bertuglia, S. Lombard and P. Nijkamp, Springer, Berlin, pp. 1-17.

Bishop, P 2008, 'Diversity and employment growth in sub-regions of Great Britain', Applied Economics Letters, vol. 15, issue 14, pp. 1105-1109.

Borzyszkowski, J, Mordawski, J \& Treder, J 1999, 'Historia, geografia i piśmiennictwo Kaszubów' ('History, geography and literature of Kashubians'), Wydawnictwo M. Rożak przy współpracy z Instytutem Kaszubskim (Publishing House M. Rożak in cooperation with Kashubian Institute), Gdańsk.(Poland)

Bosma, N \& Schutjens, V 2011, 'Understanding regional variation in entrepreneurial activity and entrepreneurial attitude in Europe', Annals of Regional Science, vol. 47, pp. 711-742.

Business entities, Local Data Bank, the Central Statistical Office, Warsaw, Available from: www.stat.gov.pl dated. 22/01/2012 (Poland)

Chaiyatorn, S, Kaoses, P \& Thitphat, P 2010, 'Ethnic Groups in the Central Region of Thailand', Journal of Social Sciences, vol. 6 issue 1, pp. 130-132.

Chlebowski, B (ed.) 1893, Słownik geograficzny Królestwa Polskiego i innych krajów słowiańskich (Geographical Dictionary of the Kingdom of Poland and other Slavic countries), Druk "Wieku" Nowy Świat 61 (print "Wieku” New World no 61), vol. XIII, Warsaw. Available from: <http://dir.icm.edu.pl/pl/ Slownik_geograficzny/Tom_XIII/3> [10 may 2011]. (Poland)

Davidsson, P \& Wiklund, J., 2001, 'Levels of Analysis in Entrepreneurship Research: Current Research Practice and Suggestions for the Future', Entrepreneurship: Theory \& Practice, vol. 25, issue 4, pp. 81-100.

de la Mothe, J \& Mallory, G 2006, 'Constructing Advantage: Distributed Innovation and the Management of Local Economic Growth', Prometheus, vol. 24, no. 1,pp. 23-36

Dochody i wydatki budżetów jednostek samorządu terytorialnego (Revenue and expenditure of local government units), Bank Danych Lokalnych (Local Data Bank), Główny Urząd Statystyczny (the Central Statistical Office), Warsaw, Available from: www.stat.gov.pl dated. 22/01/2012 (Poland)

Domański, R 2000, 'Miasto innowacyjne' ('An innovative city'), Studia KPZK PAN (Studies Committee for Spatial Economy and Regional Planning), Polish Academy of Sciences, vol. 59. (Poland)
Dutkowski, M 2002, 'Fenomen przedsiębiorczości kaszubskiej' ('The phenomenon of entrepreneurship Kashubian'), in Przedsiębiorczość i innowacyjność jako czynniki rozwoju regionalnego i lokalnego (Entrepreneurship and innovation as factors of regional and local development), ed. W Kosiedowski, UMK w Toruniu, Włocławskie Towarzystwo Naukowe (The Nicolaus Copernicus University in Toruń, Włocławek Scientific Society), Włocławek, pp. 495-506. (Poland)

Fundusze europejskie (European funds) www.mrr.gov.pl dated. 15/08/2012 (Poland)

Greblikaite, J \& Krisciunas, K 2012, 'The Development of Features of Entrepreneurship's Expression in an Enterprise', Engineering Economics, vol. 23, issue 5, pp. 525-531.

Hawkins, Ch V, 2011, 'Smart Growth Policy Choice: A Resource Dependency and Local Governance Explanation', Policy Studies Journal, vol. 39, issue 4, pp. 679-707.

Kwiatkowski, S 2002, 'Przedsiębiorczość intelektualna' ('Intellectual Entrepreneurship'), PWN (Polish Scientific Publishers PWN), Warsaw. (Poland)

Lybaert, N 1998, 'The association between information gathering and success in industrial SMEs: the case of Belgium', Entrepreneurship \& Regional Development, vol. 10, issue 4, pp. 335-351.

Mordawski, J 2008, 'Geografia Kaszub' ('Geography of Kashubia'), Zrzeszenie Kaszubsko-Pomorskie (KashubianPomeranian Association), Gdańsk. (Poland)

Obracht-Prondzyński, C 2007, 'Kaszubi dzisiaj. Kultura - język - tożsamość' ('Kashubians today. Culture - Language Identity'), Instytut Kaszubski w Gdańsku (Kashubian Institute in Gdańsk), Gdańsk. (Poland)

Phansuwan, W, Photisan, S \& Kangrang, A 2010, 'Silk-Cloth Weaving Development of the Mon -Khmer Ethnic Group in Lower-Isan', Journal of Social Sciences, vol. 6 issue 1, pp.1-3.

Sleutjes, B, Oort, F \& Schutjens, V 2012, 'A place for areabased policy? The survival and growth of local firms in Dutch residential neighborhoods', Journal of Urban Affairs, vol. 34, issue 5, pp. 533-558.

Swianiewicz, P 2012, 'Środki unijne w samorządach - kto korzysta najwięcej' ('EU funds in local government - who benefits the most'), Samorząd Terytorialny (Local Government), no. 5, pp. 9-24. (Poland)

Wang, Q 2012, 'Ethnic Entrepreneurship Studies in Geography: A Review1', Geography Compass, vol. 6, issue 4, pp. 227-240. 
Wilson, JK 2008, 'Environmental Chauvinism in the Prussian East: Forestry as a Civilizing Mission on the Ethnic Frontier, 1871-1914' Central European History (Cambridge University Press, UK), vol. 41, issue 1, pp. 27-70.
Zhang, L \& Wang, F 2010, 'Current State of Economic Returns from Education in China's Ethnic Regions and Explorations into Ways of Improvement', Chinese Education \& Society, vol. 43 , issue 5 , pp. 10-30.

Translation: Aleksandra Marta Romanowska 